\title{
MARNOTRAWSTWO NA BUDOWIE I W PRODUKCJI
}

\author{
Edyta Plebankiewicz ${ }^{\bowtie}$, Ewelina Mitera
}

Wydział Inżynierii Lądowej, Politechnika Krakowska, Kraków

\begin{abstract}
STRESZCZENIE
W artykule przedstawiono wyniki badań własnych dotyczących marnotrawstwa na budowie, które porównano do podobnych, uzyskanych w zakładach produkcyjnych. Za największy wpływ np. na koszt, czas, jakość ankietowani uznali opóźnienia w realizacji inwestycji, błędy i wady jakościowe realizowanych robót, niezgodność z przeznaczeniem, tworzenie zbędnych zapasów. Wyniki badań wskazują, że na budowie występują wszystkie główne rodzaje marnotrawstwa znane z literatury inżynierii produkcji, co potwierdza słuszność implementacji zasad ,szczupłej realizacji” ze środowiska produkcji w realizację inwestycji budowlanych.
\end{abstract}

Słowa kluczowe: Lean Manufacturing, Lean Construction, roboty budowlane, opóźnienia w realizacji inwestycji, wady jakościowe

\section{WSTĘP}

Określenia Lean Manufacturing, czyli „szczupłe” podejście do zarządzania produkcją po raz pierwszy zastosowano w „The machine that changed the world” (Womack, Jones i Roos, 1990). Opracowanie to było konkluzja badań przeprowadzonych w Massachusetts Institute of Technology na temat światowej produkcji samochodów i było inspirowane sukcesem systemu produkcyjnego Toyoty opisanego przez Taiichi Ohno (1978).

Na podstawie obserwacji pracowników w zakładzie produkcyjnym Toyoty Ohno podzielił ruchy pracowników na pracę i marnotrawstwo. Marnotrawstwo zdefiniował jako niepotrzebne, powtarzane ruchy, które trzeba jak najszybciej wyeliminować, a pracę podzielił na dodającą wartość oraz jej niedodająca, którą także uznał za marnotrawstwo. Koskela (1992) zdefiniował wartość dodaną (value-adding - VA) jako czynność, która przekształca materiał i/lub informacje w jakość oczekiwaną przez zamawiającego. Natomiast działania nieprzynoszące wartości, a wymagające czasu, zasobów lub przestrzeni Koskela podzielił na konieczne (non-value adding but requied - NVAR) i niekonieczne (non-value adding - NVA).

Literatura dowodzi, iż wprowadzenie zasad Lean Manufacturing przynosi przedsiębiorstwom produkcyjnym wymierne korzyści. W badaniach przeprowadzonych przez Jasińską, Żurek i Wyrwicką (2015) osiagnięto całkowite wyeliminowanie zbędnego ruchu, nadmiernej obróbki, a także w znacznym stopniu ograniczono marnotrawstwo w transporcie i tworzeniu niepotrzebnych zapasów. Rewers, Trojanowska i Chabowski (2015) wykazali, iż implementacja zasad „szczupłej produkcji” poprawiła bezpieczeństwo i komfort pracy, a także znacznie skróciła czas operacji.

W branży budowlanej Koskela (1992) wskazał wpływ marnotrawstwa na budowie na ponoszone koszty. Przykładowo, błędy niezgodności w jakości produktów robót to strata wielkości $12 \%$ całkowitego budżetu. Ważnym wydarzeniem w dziedzinie wdrażania filozofii Lean w budownictwie było powstanie w 1993 roku Międzynarodowej Grupy Lean Construction (IGLC), która popularyzuje rozwój w tej dziedzinie, m.in. organi-

$\varpi_{\text {eplebank@izwbit.pk.edu.pl }}$ 
zując coroczne konferencje. Na nich praktycy i naukowcy dzielą się swoimi osiagnięciami i doświadczeniami w zastosowaniu Lean Construction.

Celem artykułu jest przedstawienie wyników badań własnych dotyczących marnotrawstwa na budowie oraz porównanie ich do podobnych, przeprowadzanych w zakładach produkcyjnych.

Ohno (1978) określił siedem głównych rodzajów marnotrawstwa w zakładach produkcyjnych. Są to: nadprodukcja, oczekiwanie, przemieszczanie, niepotrzebne przetwarzanie (zbędne przetwarzanie), zapasy, ruch, wytwarzanie wadliwych części i produktów. Ponadto w literaturze wspomina się także o ósmym typie, jakim jest niewykorzystanie potencjału intelektualnego pracowników (Kruczek i Żebrucki, 2015; Wojakowski i Warżołek, 2016).

Opis tych rodzajów marnotrawstwa oraz przykłady z budowy i z zakładów produkcyjnych zestawiono $\mathrm{w}$ tabeli 1.

Tabela 1. Marnotrawstwo na budowie i w produkcji. Opis i przykłady (opracowanie własne na podstawie obserwacji oraz Shingo, 2005; Bølviken, Rooke i Koskela, 2014)

Table 1. Wastes on construction site and in production. Description and examples (own elaboration based on observations and Shingo, 2005; Bølviken, Rooke i Koskela, 2014)

\begin{tabular}{|c|c|c|c|}
\hline $\begin{array}{l}\text { Źródło marnotrawstwa } \\
\text { Waste }\end{array}$ & $\begin{array}{c}\text { Opis } \\
\text { Description }\end{array}$ & $\begin{array}{l}\text { Przykład na budowie } \\
\text { Examples on construction site }\end{array}$ & $\begin{array}{l}\text { Przykład w produkcji } \\
\text { Examples in production }\end{array}$ \\
\hline $\begin{array}{l}\text { Opóźnienia/ } \\
\text { oczekiwanie }\end{array}$ & $\begin{array}{l}\text { Marnotrawstwo w przepływie } \\
\text { pracy, oczekiwanie na robotę } \\
\text { budowlaną/produkt/usługę }\end{array}$ & $\begin{array}{l}\text { Opóźnienie oddania robót } \\
\text { murarskich i oczekiwanie } \\
\text { brygady tynkarzy na front robót }\end{array}$ & $\begin{array}{l}\text { Brak pociętych kartonów, } \\
\text { w które można spakować } \\
\text { wyroby tytoniowe }\end{array}$ \\
\hline $\begin{array}{l}\text { Błędy i wady } \\
\text { jakościowe } \\
\text { niezgodność } \\
\text { z przeznaczeniem }\end{array}$ & $\begin{array}{l}\text { Tworzenie produktów/usług } \\
\text { niezgodnych z oczekiwaniem } \\
\text { klienta }\end{array}$ & $\begin{array}{l}\text { Zastosowanie płyt G-K } \\
\text { nieimpregnowanych (białych } \\
\text { zamiast zielonych) w łazienkach }\end{array}$ & $\begin{array}{l}\text { Wieko paczki papierosów lekko } \\
\text { otwarte }\end{array}$ \\
\hline Zapasy & $\begin{array}{l}\text { Składowanie materiałów lub } \\
\text { produktów pośrednich aktualnie } \\
\text { lub w najbliższym okresie } \\
\text { zbędnych, nieprzetwarzanych }\end{array}$ & $\begin{array}{l}\text { Zamawianie zbyt dużej ilości } \\
\text { materiałów, które wymagają } \\
\text { obszernego miejsca składowania }\end{array}$ & $\begin{array}{l}\text { Magazynowanie dużej ilości } \\
\text { produktów gotowych }\end{array}$ \\
\hline $\begin{array}{l}\text { Niewykorzystany } \\
\text { potencjał pracownika }\end{array}$ & $\begin{array}{l}\text { Niewykorzystanie umiejętności, } \\
\text { doświadczenia, wykształcenia } \\
\text { pracowników }\end{array}$ & $\begin{array}{l}\text { Zatrudnienie doświadczonego } \\
\text { pracownika na niskim } \\
\text { stanowisku }\end{array}$ & $\begin{array}{l}\text { Zatrudnienie doświadczonego } \\
\text { pracownika na niskim } \\
\text { stanowisku }\end{array}$ \\
\hline $\begin{array}{l}\text { Nadmierne } \\
\text { przetwarzanie }\end{array}$ & $\begin{array}{l}\text { Wykonywanie czynności } \\
\text { niepotrzebnych, niewydajnie. } \\
\text { Marnotrawstwo związane } \\
\text { z szybkością, metodą } \\
\text { i potrzebami przetwarzania }\end{array}$ & $\begin{array}{l}\text { Nieoptymalne wykorzystanie } \\
\text { materiału, maszyny, energii } \\
\text { i pracy, strata materiału }\end{array}$ & Ruchy jałowe narzędzi \\
\hline Zbędny transport & $\begin{array}{l}\text { Niepotrzebne przemieszczanie } \\
\text { produktów i półproduktów }\end{array}$ & $\begin{array}{l}\text { Przenoszenie półproduktów } \\
\text { potrzebnych brygadzie } \\
\text { następującej, aby udostępnić } \\
\text { działkę brygadzie poprzedzającej }\end{array}$ & $\begin{array}{l}\text { Zbyt długa trasa } \\
\text { przemieszczania półproduktów } \\
\text { na następne stanowisko }\end{array}$ \\
\hline Nadprodukcja & $\begin{array}{l}\text { Nieodpowiednia wydajność } \\
\text { produkcji. Półprodukty/ produkty/ } \\
\text { usługi wytwarzana są za wcześnie } \\
\text { lub w za dużej ilości }\end{array}$ & $\begin{array}{l}\text { Realizacja podejść } \\
\text { instalacyjnych zanim elementy } \\
\text { wyposażenia zostaną wybrane, } \\
\text { np. stelaż, miska ustępowa }\end{array}$ & Produkcja na wszelki wypadek \\
\hline Zbędny ruch & $\begin{array}{l}\text { Zbędny wysiłek fizyczny } \\
\text { wykonywany przez pracownika }\end{array}$ & $\begin{array}{l}\text { Zbyt oddalone składowanie } \\
\text { materiałów potrzebnych } \\
\text { w danej robocie, zmuszające do } \\
\text { niepotrzebnych przemieszczeń }\end{array}$ & $\begin{array}{l}\text { Sięganie po niewłaściwe } \\
\text { narzędzie }\end{array}$ \\
\hline
\end{tabular}




\section{MATERIAt I METODY}

Marnotrawstwo wymienione w tabeli 1 zostało poddane ocenie wykonawcom robót budowlanych, aby sprawdzić jego wpływ np. na koszt, czas, jakość robót oraz stopień występowania w realizacji inwestycji budowlanych. W tym celu do dnia 23.02.2017 roku wysłano (w pliku MS Word do wypełnienia lub link do strony z elektroniczną ankietą - http://www.ebadania.pl/2d3bef0db0b846a9, dostęp z dnia 23.02.2017) lub przekazano osobiście ankiety w liczbie 390 sztuk.

Arkusz pytań do wypełnienia przez respondentów składa się z dwóch głównych części. Pierwsza z nich bada sylwetkę respondentów, tzn. firmę, z jakiej pochodzą, doświadczenie, inwestycje, przy jakich pracowali. Druga to tabela $\mathrm{z}$ czynnikami marnotrawstwa na budowie do oceny przez ankietowanych w dwóch kategoriach: częstość występowania i ważność/wpływ np. na koszt, czas, jakość. Do dnia 23.02.2017 roku otrzymano $6,67 \%$ poprawnie wypełnionych ankiet. Większość respondentów okazała się być pracownikami dużych przedsiębiorstw (62\% w firmach zatrudniających powyżej 250 pracowników), będących generalnym wykonawcą (84\%), na budowach realizowanych w tradycyjnym systemie - Design-Bid-Build (65\%). Ponadto są to osoby z dużym doświadczeniem (31\% badanych ma 11-20 lat doświadczenia, 23\% - 6-10 lat, a 19\% - powyżej 20 lat) i na wysokim stanowisku ( $48 \%$ to dyrektorzy/dyrektorzy kontraktu/kierownicy kontraktu/kierownicy budowy) - rysunek 1.

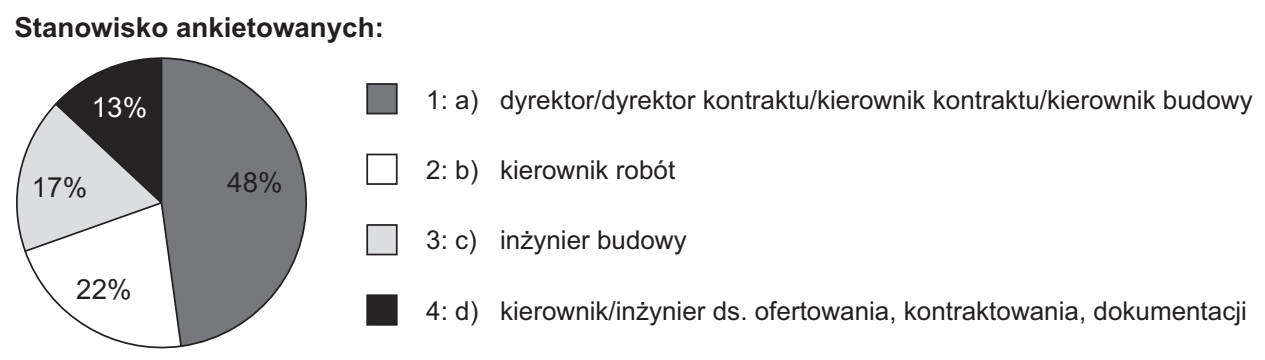

Firma, w której pracuje ankietowany zatrudnia średniorocznie stałych pracowników (kadrę zarządzającą, inżynierską, administracyjną, fizyczną itd.):

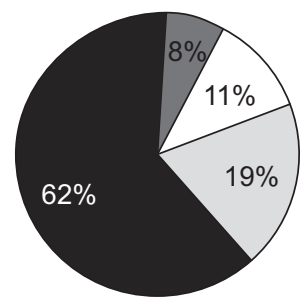

1: a) do 9 pracowników stałych

2: b) od 10 do 49 pracowników stałych

3: c) od 50 do 249 pracowników stałych

4: d) powyżej 250 pracowników stałych

Doświadczenie ankietowanych w pracy na budowie:

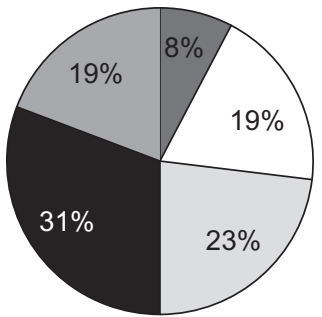

1: a) mniej niż 2 lata

2: b) 3-5 lat

3: c) 6-10 lat

4: d) 11-20 lat

5: e) powyżej 20 lat

Rys. 1. Sylwetka respondentów

Fig.1. Characteristics of respondents 
Respondenci mieli ocenić marnotrawstwo w skali od 1 do 4 ze względu na stopień jego występowania, gdzie: 1 - marnotrawstwo nie występuje lub występuje bardzo rzadko, 2 - występuje czasami, 3 - występuje często, 4 - występuje zawsze.

Ankietowani określili także stopień ważności/wpływu danego marnotrawstwa np. na koszt, czas, jakość, gdzie: 1 - żaden wpływ lub jego pomijalny wymiar (nieważny), 2 - niewielki wpływ (mało ważny), 3 - średni wpływ (średnio ważny), 4 - duży wpływ lub znaczny wpływ (bardzo ważny).

\section{WYNIKI I DYSKUSJA}

Na podstawie otrzymanych ocen obliczono średnie arytmetyczne odpowiedzi oraz dominanty, które wskazywały odpowiedź występująca najczęściej („brak” oznacza, że co najmniej dwie oceny występowały równie czesto). W tabeli 2 rodzaje marnotrawstwa uszeregowano według średniej arytmetycznej stopnia ich występowania. Szczegółową ocenę dotyczącą oceny występowania marnotrawstwa na budowie podano w kolumnie B, natomiast w kolumnie $\mathrm{C}$ - stopień ich ważności/wpływu np. na koszt, czas, jakość. W tabeli przedstawiono także wyniki badań stopnia występowania marnotrawstwa w przedsiębiorstwach produkcyjnych. „Produkcja 1” dotyczy wyników badań Lisieckiej i Burki (2015) przeprowadzonych w przedsiębiorstwach o charakterze produkcyjno-usługowym branży ciepłowniczej. Ankietowani oceniali natężenie występowania poszczególnych grup marnotrawstwa w skali od 0 do 5, gdzie: 0 - marnotrawstwo nie występuje, 0,01-1,99 - marnotrawstwo występuje w niewielkiej ilości, 2-2,99 - występuje średnia ilość marnotrawstwa, 3-5 - występuje duża ilość marnotrawstwa (niezbędne są natychmiastowe działania zaradcze).

W tabeli 2 w kolumnie „Produkcja 2” zawarto wyniki badań Wojakowskiego i Warżołek (2016), które określają procentowy udział siedmiu głównych rodzajów marnotrawstwa w analizowanym przedsiębiorstwie branży motoryzacyjnej.

Wykonawcy robót budowlanych ocenili opóźnienia w realizacji inwestycji i oczekiwanie jako najczęstsze i najważniejsze $\mathrm{z}$ wymienionych w tabeli 1 i 2 rodzajów marnotrawstwa. W generalnym wykonawstwie roboty zamawiane są często na konkretne zakresy robót. Przykładowo inna firma wykonuje roboty murarskie, inna wykończeniowe. Umowne daty rozpoczęcia robót danej brygady mogą przesunąć się w czasie z uwagi na opóźnienia $\mathrm{w}$ realizacji brygady poprzedzającej.

W dalszej kolejności respondenci wysoko ocenili zarówno pod względem stopnia ważności, jak i stopnia występowania niewykorzystany potencjał pracownika, czyli umieszczanie pracowników na stanowiskach niezgodnie z ich wykształceniem i umiejętnościami. Zarówno na budowie, jak i w produkcji umieszczenie pracownika na złym stanowisku wiąże się z marnotrawstwem. Osoba niewykwalifikowana może nie poradzić sobie z ciężarem odpowiedzialności, oddając robotę/produkt niezgodny z oczekiwaniem klienta i nie w terminie. Może to także wiązać się z dodatkowymi kosztami spowodowanymi np. naprawą błędów, do których się przyczyniła. Niewykorzystanie potencjału osoby wykwalifikowanej, której można by powierzyć większy zakres prac lub wpływający np. na większy koszt prac, także wiąże się z marnotrawstwem istotnym z punktu widzenia wykonawcy.

Równie często ankietowani ocenili występowanie zbędnego ruchu. Niepotrzebne przemieszczanie się pracowników, zła organizacja miejsca pracy, a przez to szukanie potrzebnego sprzętu przyczynia się do marnotrawstwa. Ankietowani uznali, iż czasami na budowie występuje zbędny transport. Może być to związane ze złą logistyką na placu budowy, prowadzącą do zbędnych przemieszczeń materiałów z miejsca na miejsce. Podobną częstotliwość respondenci wskazali dla zapasów oraz nadmiernego przetwarzania. Wynika to stąd, że firmy starają się kontrolować miejsca składowania materiałów. Nadmierne przetwarzanie to czynności, które nie są wymagane, a jednak wykonywane, czyli zbędne. Spośród siedmiu głównych rodzajów marnotrawstwa opisanych przez Ohno (1978) za najrzadziej występujące na budowie wykonawcy robót wskazali nadprodukcję.

Spośród wymienionych w tabeli 2 czynników marnotrawstwa ankietowani za najważniejszy w budownictwie, mający największy wpływ np. na koszt, czas, jakość, uznali opóźnienia w realizacji inwestycji. 
Tabela 2. Wyniki ankiet dotyczących źródeł marnotrawstwa występującego w zakładach produkcyjnych i na budowie. Kolumna A-C: opracowanie własne (budowa), kolumna D (produkcja): opracowanie własne na podstawie Lisieckiej i Burka (2015), kolumna E (produkcja): opracowanie własne na podstawie Wojakowskiego i Warżołka (2016)

Table 2. The result of questionnaire research - wastes on construction site and in production. Column A-C: own research (construction); column D (production): own elaboration based on Lisiecka i Burka (2015), column E (production): own elaboration based on Wojakowski and Warżołek (2016)

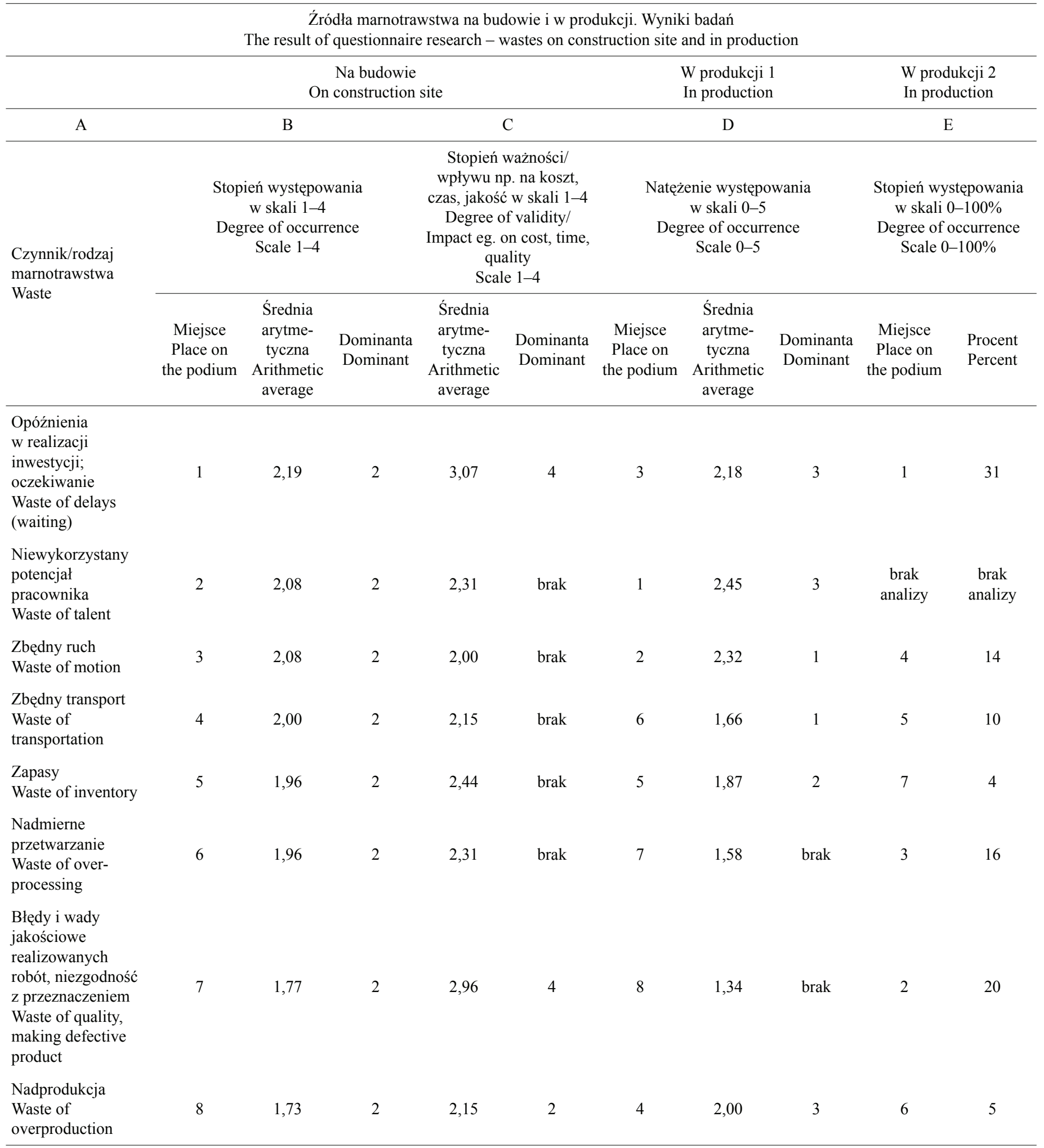


Wykonawcy robót budowlanych w umowie z zamawiającym mają przeważnie uwzględnione kary umowne za niedotrzymanie terminu realizacji, stąd też wysoka ocena ankietowanych.

Kolejnym wysoko ocenianym pod względem wpływu np. na koszt, czas, jakość źródłem marnotrawstwa na budowie są błędy i wady jakościowe realizowanych robót lub/i niezgodność z przeznaczeniem. Obecnie zamawiający coraz częściej korzysta z usług przedsiębiorstw zarządzających realizacjami budowlanymi, które dysponują wykwalifikowaną kadrą sprawdzającą jakość wykonywanych przez wykonawcę robót. Niewykonanie ich zgodnie ze specyfikacją prowadzi do konieczności poprawy, a co za tym idzie, kolejnego marnotrawstwa - czas, jaki jest potrzebny na korektę, a być może i zakupienie nowych produktów do jego realizacji.

Następną pozycją pod względem ważności są zapasy. Przykładowo, w związku z coraz większym zurbanizowaniem miast inwestycje budowane w centrum mają coraz mniej miejsca do dyspozycji na składowanie materiałów. Częściowo teren może być dzierżawiony od sąsiada lub zamawiającego, np. z pierwszego etapu realizacji inwestycji, czyli im większa powierzchnia takiego terenu, tym większe koszty wynajmu. Marnotrawstwo zbędnego transportu oceniono przez wykonawców robót budowlanych jako mało ważny i występujący czasami, podobnie jak nadprodukcja. Najniżej pod względem wpływu np. na koszt, czas, jakość ankietowani uznali marnotrawstwo wynikające ze zbędnego ruchu.

Respondenci analizowanych przedsiębiorstw branży ciepłowniczej (Produkcja 1) oraz motoryzacyjnej (Produkcja 2), podobnie jak w produkcji budowlanej, uznali opóźnienia, oczekiwanie za najcześciej lub prawie najczęściej występujące marnotrawstwo $\mathrm{z}$ wymienionych w tabeli 1 i 2 . W zakładzie produkcyjnym, w systemie produkcyjnym Toyoty, na którym opiera się Lean Manufacturing, towar realizowany jest zgodnie z zamówieniem klienta, z którym również określa się termin realizacji, a zatem opóźnienia wpływają na umowę zawarta z zamawiającym. Ankietowani Produkcji 1 z przedsiębiorstwa o charakterze produkcyjno-usługowym za najczęściej występujące marnotrawstwo w tabeli 2 uznali niewykorzystany potencjał pracownika. Badane przedsiębiorstwa produkcyjno-usługowe branży ciepłowniczej wskazały średnio częstą ilość tegoż marnotrawstwa, częste w stosunku do pozostałych.

Kolejnym wysoko ocenianym źródłem marnotrawstwa pod względem częstotliwości uznano błędy i wady jakościowe, niezgodność z przeznaczeniem. System produkcyjny Toyoty to między innymi autonomizacja, zwana także (z jap.) jidoka, która powoduje zatrzymanie się linii lub odrzucenie wadliwego półproduktu/produktu w chwili wykrycia przez czujki wady. Wiąże się to, podobnie jak na budowie, z dodatkowym marnotrawstwem czasu, a także kosztami, jeśli produkt nie nadaje się już do dalszej obróbki. Gdy maszyna często wyrzuca wadliwe produkty, należy skierować ją do naprawy. Gdy produkcja na tej maszynie jest wyspecjalizowana i nie można produktów wykonać na innej, to dana produkcja jest wstrzymana, co wiąże się z dużą stratą kosztów. Nie jest to jednak powszechne marnotrawstwo, o czym wskazuje rozbieżność w stosunku do Produkcji 1, dla której marnotrawstwo to jest dopiero na 8 miejscu. Tam częstszy okazał się zbędny ruch.

Ohno (1978) w swojej pracy zwrócił uwagę, że obserwacja pracownika może pomóc wyeliminować to marnotrawstwo, zaznaczając, które ruchy są zbędne i zachęcając do poprawy. Poza efektywnością pracownika ważna jest także efektywność maszyny. Jeśli wymaga nadmiernego przetwarzania, to wiąże się to z marnotrawstwem, co, jak wskazują badania w Produkcji 2, występuje często w stosunku do pozostałych pozycji tabeli. Powodem mogą tu być jałowe ruchy narzędzi. Autorki konsultowały także marnotrawstwo ze specjalistą zakładu produkcyjnego wyrobów tytoniowych. Zwrócił on uwagę, że niekiedy nadmierne przetwarzanie nie jest winą maszyny, a półproduktu, który jest nieodpowiednio przygotowany. Na przykład owijana w polipropylen paczka wyrobów tytoniowych, dla której opakowanie jest sprowadzane z zagranicy, wymaga czasem leżakowania. Zmiana klimatu może spowodować zawilgocenie, które należy osuszyć, w innym wypadku wilgoć może spowodować przyklejanie się do siebie części i nadmierne przetwarzanie przez maszynę, która musi w etapie końcowym przekazać produkt spełniający standardy przedsiębiorstwa.

Ohno (1978) ocenił nadprodukcję za szczególnie istotną. Nadprodukcja, czyli wytwarzanie produktów i usług z wyprzedzeniem lub w większej ilości, niż jest to niezbędne w danej chwili, wiąże się z dodatkowym 
materiałem niezamawianym przez klienta lub nieskoordynowanym z innymi etapami linii produkcyjnej, a zatem prowadzące do konieczności magazynowania. Taki system to przykład masowej produkcji w zakładach produkcyjnych z czasów Henry’ego Forda w USA, który był opłacalny, póki nie zaczął konkurować z zakładem Toyoty z bogatszym wachlarzem modeli. W przypadku przedsiębiorstw, w których wykorzystano narzędzia Lean Management, nie powinno stanowić to głównego problemu, ponieważ produkowane jest tyle, ile zostało zamówione przez klienta. W zakładach produkcyjnych nierealizowanie produktów zgodnie z techniką just-in-time, czyli dokładnie na czas i według kart kanban, które określają ilość potrzebnych produktów/półproduktów, wiąże się z koniecznością posiadania magazynów, a zatem z dodatkowym kosztem. Marnotrawstwa tego można jednak uniknąć, zamawiając półprodukty w ilości adekwatnej do zamówień klienta.

Marnotrawstwo zbędnego transportu w stosunku do pozostałych wymienionych w tabeli nie zostało ocenione jako często występujące. Oznaczać to może, że logistyka w zakładach jest przemyślana.

\section{PODSUMOWANIE I WNIOSKI}

Lean Construction, która ma na celu usprawnienie realizacji inwestycji budowlanych poprzez maksymalizację wartości dodanej i eliminację marnotrawstwa, wywodzi się z metody Lean Manufacturing, powstałej z analizy linii produkcyjnych. Autorki przeprowadziły badania nad marnotrawstwem na budowie. Do dnia 23.02.2017 roku uzyskano dane od 26 respondentów. Ankietowanymi były osoby z dużym doświadczeniem i pracujące głównie w dużych przedsiębiorstwach, zatrudniających powyżej 250 pracowników stałych, oraz będacych generalnym wykonawcą robót budowlanych. Oceniły one stopień występowania i ważność, wpływ np. na koszt, czas, jakość robót budowlanych marnotrawstwa. Okazało się, że wszystkie główne rodzaje marnotrawstwa znane z literatury inżynierii produkcji występują także na budowie, co potwierdza słuszność implementacji zasad „szczupłej realizacji” ze środowiska produkcji w realizację inwestycji budowlanych. Za największy wpływ np. na koszt, czas, jakość ankietowani uznali opóźnienia w realizacji inwestycji, błędy i wady jakościowe realizowanych robót, niezgodność z przeznaczeniem, tworzenie zbędnych zapasów.

Autorzy zwracają uwagę, iż badania wskazują kierunki, którym należy się przyjrzeć, by usprawnić realizację robót, jednakże należy pamiętać, że każda budowa, a także zakład produkcyjny mają indywidualny charakter i by osiagnąć lepsze wyniki, należałoby dokładniej zbadać źródła marnotrawstwa. Do ich znajdowania może posłużyć np. metoda 5 Whys, diagram Ishikawy. Następnie warto sprawdzić przepływ wartości z wykorzystaniem narzędzi, tj. VSM, The Last Planner. Mapowanie strumienia wartości (Value Stream Mapping - VSM) polega na analizie przepływu materiałów/robót/usług/informacji w formie graficznej od fazy początkowej do tzw. idealnej z produktem/robotą/usługą gotową w planowanej formie (więcej np. w Womack, Jones i Roos, 1990; Shook i Rother, 2009). The Last Planner ${ }^{\circledR}$ skierowany do inwestycji budowlanych, wykreowany przez Ballarda i Howella i licencjonowany przez Lean Construction Institute, polega na analizie przepływu pracy, tworząc cotygodniowe plany, pozwalające usprawnić realizację, wskazując źródła marnotrawstwa do eliminacji (więcej np. w Hussain, Krishna i Kumar, 2014).

\section{PIŚMIENNICTWO}

Bølviken, T., Rooke, J. i Koskela, L. (2014). The wastes of production in construction - a TRV based taxonomy. Proceedings of IGLC22, Oslo.

Hussain, S., Krishna, B. i Kumar, V. (2014). Application and analysis of Last Planner System in the construction industry. IMPACT: International Journal of Research in Engineering \& Technology, 6(2), 33-34.

Jasińska, S., Żurek, M. i Wyrwicka, M. K. (2015). Analiza efektywności wdrożenia Lean Manufacturing. Studium przypadku. Economics and Management, 1, 311-323. doi:10.12846/j.em.2015.01.19.

Koskela, L. (1992). Application of new production Philosophy to Construction. Stanford: Technical Report. 
Kruczek, M. i Żebrucki, Z. (2015). Koncepcja lean management w procesie ciągłego doskonalenia przepływów. Logistyka, 2, 425-432.

Lisiecka, K. i Burka, I. (2015). Źródła powstawania marnotrawstwa w organizacjach na przykładzie usługowych przedsiębiorstw ciepłowniczych. Studia Ekonomiczne. Zeszyty Naukowe Uniwersytetu Ekonomicznego w Katowicach, 233, $75-91$

Ohno, T. (1978). The Toyota Production System: Beyond Large-Scale Production. Tokyo: Diamond Publishing.

Rewers, P., Trojanowska, J. i Chabowski, P. (2015). Analiza wykorzystania narzędzi Lean Manufacturing - wyniki badań. Logistyka, 3, 5788-5791.

Shingo, S. (2005). A Study of the Toyota Production System. New York: Productivity Press.

Shook, J. i Rother, M. (2009). Eliminacja marnotrawstwa poprzez mapowanie strumienia wartości. Wrocław: Lean Enterprise Institute.

Wojakowski, P. i Warżołek, D. (2016). Wdrożenie 5S w przedsiębiorstwie produkcyjnym z branży motoryzacyjnej. Gospodarka Materiałowa \& Logistyka, 11(1239), 20-331.

Womack, J. P., Jones, D. T. i Roos, D. (1990). The machine that changed the world. New York: Macmillan.

\section{THE WASTES ON CONSTRUCTION SITE AND IN PRODUCTION}

\section{ABSTRACT}

The article presents the results of the study on the waste on construction site. The results were compared to similar data obtained in the production. According to the respondents the greatest impact, eg. on the cost, time and quality have: the delay (waiting) in the construction, lack of quality and making defective product in construction works as well as lack of intended use creating unnecessary inventory. The results show that the main waste mentioned in the production engineering literature are present also on the construction site, which confirms the need of implementation of Lean Manufacturing principles to the construction projects.

Key words: Lean Manufacturing, Lean Construction, construction works, delays in realization of construction works, qualitative defects 